\title{
PHILOSOPHY, A CHALLENGE TO POST-TRUTH, ALSO IN INDONESIA
}

\section{Franz Magnis-Suseno SJ}

Driyarkara School of Philosophy

Email: magnis.sj@gmail.com

\section{Abstract}

This article insists that it is the task of philosophy to challenge untruth under the guise of truth. In the first part the author follows how philosophy changed from teachings of wisdom to critique of false truth claims: beginning with Eastern philosophy, with special consideration of Javanese wisdom, through Greek philosophy where philosophy comes into its own right, to Medieval philosophy, until enlightenment clearly establishes philosophy as criticism. Hegel and Critical Philosophy are given special attention. In the second part the author stresses the importance of critical philosophy for Indonesia. He exemplifies this on three widely accepted untruths: untruth about what happened in Indonesia in 1965 and 1966, the claim that Pancasila is incompatible with liberal democracy, and the claim of religious extremism to present truth about religion. The article ends with appeal to defend our democratic freedoms without compromise.

Keywords: post-truth, untruth, philosophy, wisdom, critical philosophy, Pancasila, religion.

\section{Abstrak}

Artikel ini menegaskan bahwa adalah tugas dari filsafat untuk menentang ketidak-benaran yang bersembunyi dibalik selubung kebenaran. Pada bagian pertama, penulis menjelaskan bagaimana filsafat mengalami perubahan dari ajaran tentang kebijaksanaan ke upaya kritik atas klaim-klaim kebenaran palsu: bermula dari filsafat Timur, dengan perhatian khusus pada kebijaksaan Jawa, melalui filsafat Yunani di mana filsafat berdiri pada posisinya sendiri, menuju filsafat Abad Tengah, hingga masa pencerahan, cukup tegas menunjukkan filsafat sebagai tradisi kritis. Hegel dan Filsafat Kritis mendapat perhatian khusus. Pada bagian kedua penulis menegaskan pentingnya tradisi filsafat kritis untuk Indonesia. Penulis 
menyontohkan hal ini pada tiga fenomena ketidak-benaran yang secara luas telah diterima sebagai benar: ketidak-benaran tentang apa yang terjadi di Indonesia pada tahun 1965 dan 1966, klaim bahwa Pancasila tidak selaras dengan demokrasi liberal, dan klaim tentang ekstrimisme agama untuk menunjukkan kebenaran pada agama. Artikel ini diakhiri dengan ajakan untuk mempertahankan kebebasan dalam demokrasi tanpa kompromi.

Kata-kata kunci: Post-truth, untruth, filsafat, kebijaksanaan, filsafat kritis, Pancasila, agama.

\section{INTRODUCTION: THE CHALLENGE OF POST TRUTH}

Post-truth has become a powerful fact. Because post-truth makes grasps for power easier. As says the Term of Reference of the conference: "Hoaxes, false news and fabricated information were massively spread and mostly accepted as facts and truth by large part of the Indonesian public". Quoting from the English Dictionary the TOR defines 'post-truth' as a "situation in which public discourse is shaped by emotions, personal belief, or 'felt truth' rather than objective facts and scholarly findings". Or, as my colleague Dr. Setyo Wibowo writes, the term is used when speaking about "not believing data/facts, refusing to think rationally, (even) openly lying" (Wibowo, 2019). Post-truth is corrupting our politics, it is even corrupting our religious substance. Post-truth is corrupting us, because post-truth means giving respectability to lying, and nothing of worth and substance can be built on lies. Post-truth means degradation of honesty, while without honesty we can no longer trust each other, we can only manipulate each other, and that means the end of any positive community.

Humans have, of course, lied at all times. Humans lied to get undeserved advantages, they lied to escape punishment, to run from responsibilities, to hit adversaries, to impress people. Nothing new. But the term post-truth adds something to mere lying. Maybe, it does not completely wash lying clean. But it insinuates that falsehood, disregard for facts, basing oneself on one's strong emotions and subjective convictions have gained a certain respectability, as a new way of getting things done in the 21st century. Post-truth even 
insinuates a democratic openness, thru the social media, where the number of "likes" und "dislikes" are more important than what, to use the old-fashioned term, is really the case.

Facing post-truth, I want to make my point clearly: This creeping respectability of post-truth has to be resolutely destroyed. Post-truth has no respectability. Post-truth behavior is lying, and lying is wrong, and has to be clearly stigmatized as wrong, for (at least) two reasons: Firstly, by lying people that have no right to it get power over us. Secondly, not only humans, no organism can live from lies or imaginations: truth, the knowledge of what thing are and where they are is absolutely vital for our survival. In order to survive you need real rice, not phantasies about rice. You win elections if you get a majority of the votes of the electorate, and not if you proclaim yourself confidently as the winner. And we will get our country only closer to our ideals of becoming an Indonesia that is independent, sovereign, united, just, prosperous, progressive, civilized if we have really qualified leaders and a people with the competences, real competences, are needed.

Thus, we have to challenge post-truth. And the one human endeavor that is a challenger of post-truth par excellence is philosophy. Thus, I want to talk about philosophy.

Of course, it has to be acknowledged that philosophy too can be infiltrated by post-truth. Setyo Wibowo points to postmodernism. He quotes Lee McIntyre: "Thus is postmodernism the godfather of posttruth" (Wibowo, 2019). I quote again Setyo Wibowo: "Truth is said not to exist, objectivity is disregarded as false claim" (ib.).

But such philosophy makes itself superfluous. We don't need sophisticated lies, spun out by philosophers. Even postmodernism can still be understood as critique of philosophies in the name of truth. In this presentation I want to make the point that it is the task of, and a challenge to, philosophy to defrag post-truth. I want to show that from its very beginning, philosophy was the way the sharpest minds of humanity pitilessly challenged and forced down half-truths, lies, false promises and false dreams - in the name of what is true. Thus, philosophy is essentially the intellectual challenge to untruth, and thus to post-truth. The real task of philosophy is not teaching doctrines of wisdom, but criticizing them in order to free 
themselves from half-truths, deceptions and pursuing the wrong track. Philosophy is essentially the science of critique. This article will take a short journey through the history of philosophy.

\section{DISCUSSION: A SHORT JOURNEY THROUGH THE HISTORY OF PHILOSOPHY FROM WISDOM TO CRITIQUE}

Philosophy made her entry on the world stage thru the great systems of thinking in the East, particularly in India and China. In India teachings of how we were posited in the whole realm of reality, thru the teachings of karma, gave people orientation how to live in a positive, realistic and promising way. The Buddha (483-400 BC) showed his people how get out of the fetters of suffering and reach real internal freedom. Kong Fu-tzu (551-479 BC) made people understand that by trying to finding one's essential situation one would no long be an object of arbitrary and incidental factors, but could find one's line of life. Lao-Tzu (601-Qin BC) taught people to always look for their dao instead of being driven by anarchical passions and wild interests. Wise people would follow these teaching. They experienced that their lives were saved from shallowness, got depth and an internal logic. These philosophies were criticism, criticism of superficial, shallow, shortsighted, in the end frustrating ways of life, but still they were primarily teachings of wisdom. Wise people would let themselves lead by them. But because they taught wisdom, they criticized ways of living that were erroneous, that they could not keep their promises of leading to happiness. Their wisdom opened the eyes of their followers to why trying to force one's interests would not lead to freedom and why trying to fulfill every felt need did not lead to fulfillment. They let people see the untruth of cheap promises of fulfillment.

There were two typical sides of these Eastern philosophies of wisdom. They were not strictly divided from religion. In fact, the teachings in these holy books, of the Buddha, of Kong Fu-tzu and Lao-Tzu were religion, showed people how to put themselves into a positive, meaningful, hope offering position in relation to the whole universe. They offered ways to salvation. And therefore, this is the second point, these philosophies were not so much the business of professional philosophers, of small groups of intellectuals, but 
offered ways to conduct one's life to the whole community. These teachings of wisdom became, up to this day, the way big cultures prayed, where they confessed their sins and hoped for salvation.

\section{A NOTE ON JAVANESE WISDOM}

The same holds for Javanese philosophy. Javanese philosophy teaches wisdom in the sense that it promises to gradually free its followers from feelings of unease (resah) and social conflict. Javanese wisdom is at the same time criticism of half-truths, superficiality, of chasing for immediate fulfillment instead of opening up to deep fulfillment.

Take Bima, better known as Werkudara, this powerfully built second of the Pandawa brothers. Nobody can defeat him. He is a kind of superhero. But Javanese know, they learn it in the story of Dewaruci, that Werkudara's real power does not lie in his muscles, even not in his magical fingernails pancanaka, but in his inner wealth. Meeting his interior essence, Dewaruci, he opens up finally to the Divine itself, he understands that all the external world is contained in his inner world, thus that his enormous power streams from the divine depths at the bottom of his being. Bima, therefore, becomes humble, he just does his duties, concealing his deep-dimension, thereby helping his brothers to win the Bratayudha war. Javanese know that real strength never boasts, that you can, and will, win without an army, winning without humiliating.

Javanese wisdom reminds us always to remember, éling. Remember who we are, who I am, where I come from. Remember what? Ah, to remember Javanese are told to deepen their existential feeling, their rasa. Javanese understand, or know, or, still better, realize their essence, their origin, their rootedness in the universe by deepening their rasa, their feeling. In the Wédhatama Javanese are taught to offer (sembah) their being in four stages: sembah raga, the disciplining of one's body, meant are the external forms of praying; then sembah karsa (the offering of one's will), and sembah cipta (the offering of one's thoght). But the deepest, essential sembah is the sembah rasa, the offering of one's inner feeling; only in this fourth offering a person penetrates to the divine, opening up to mystical experiences, "uniting with the Lord" (manunggaling kawula Gusti). 
Thus, what Javanese are told to remember is nothing else than Sangkan Paraning Dumadi, the origin and final destination of their existence. This is what Bima reached entering the left ear of Dewaruci. In all kind of things Javanese have or want to do they are reminded of éling, meaning never losing awareness of from where they come and where they will go.

Of course, éling can also be corrupted. It can be made to support interests of power. Thus, while proclaiming metaphysical modesty the upper classes can, and mostly will, decisively block any attempt by the lower classes to draw social-political conclusions from the metaphysical insight that, before the Divine, there is no difference between those on top and those below. Take the Punakawan. They are the faithful servants of their lords, following, often guiding them on their journeys. There is a big difference between the Pandawa, the noble knights, beloved by the spectators, and their enemies, the mean spirited Kurawa. The Pandawa always treat their servants with respect, knowing that in deeper reality they depend on their servants. They always listen to the Punakawan, while the Kurawa never listen to their punakawan, Togog and mBilung, to their chagrin. But there is a wayang play called Petruk dadi ratu, Petruk (the cleverest of the Pandawa servants) becomes king. He clearly doesn't fill his role as king. At one point the dhalang says: Katoné kaya ksatriya, ambuné kaya wedhus, he looks like a knight, but he smells like a goat: A very effective way the feudal upper classes make everybody know where his or her place in society is. They do respect their servants Javanese spectators, of course, know, that real power resides in the punakawan, particularly in Semar, and that, without Semar, the Pandawa cannot achieve anything, - but servants have to be servants and should not try to become noble man. Has Karl Marx seen this screen play when writing about ideology?

\section{GREEK AND MEDIEVAL PHILOSOPHY}

About 2500 years ago there happened something extraordinary in a small spot of the world, called Greek. Real philosophy, in our modern sense, was born. A philosophy that did not become a religion, but philosophy in the sense of a science of critical discourse among competent intellectuals. Greek philosophy grew out of 
dissatisfaction with traditional religion and morals. Philosophers like Parmenides (515-470 BC), Herakleitos (540-480 BC), but also Pythagoras (570-495 BC) were searching for was really the essence of the world.

But let as look at the two giants of philosophy who even today, more than 2000 years later and in a very different world, challenge our thinking, Platon (429-347 BC) and Aristoteles (384-332 BC). Both taught wisdom, but critical wisdom, wisdom to help their followers to free themselves from superficial, shallow views. Platon taught that real knowledge is elicited by love. We should free ourselves from doxa, opinions based merely on the everchanging figures of our sensual world, so to penetrate to the eternal ideas behind them, finding wisdom. 2300 years later Friedrich Nietzsche (1844-1900) would point to Platon's philosophy as the original sin of philosophy and religion because, according to him, Platon did, what religions do, throw our responsibility to an afterworld and embracing a morality of servants. Back to Greece. Aristoteles, by distinguishing sharply between sophia and phronesis, criticized Platon's idea that the community should be headed by philosophers. Since politics take place in a continuously changing world, to become a leader, experience and practical knowledge are demanded, not vision of unchanging ideas. Ethics were not a science, but practical knowledge one can only learn by experience. Aristoteles made the point, that our sensible physical social world is the real one, not a realm of ideas, by his extremely influential hylemorphism where the distinctions between form and matter, substance and accidents, formal, material, efficient and final causes became for two thousand years main instruments of philosophical thinking. Philosophy as systems of thinking was born in Greece.

But at the same time a completely new factor entered the stage, monotheistic religions, Judaism, Christianity and Islam. For them, Divinity was not a final principle from where reality emanated, but the Divine as a personal God. Yahweh, Allah spoke to us humans and we could address Him. God was a You, who would listen to us, to whom we all, individually, whether man or women, king or beggar, freeman or slave, could speak, ask for help and forgiveness. And this God spoke to us thru His revelation. He told us who He 
was, what we were - namely created personally and in love by God, and how he wanted us to live. From God's own revelation we knew how we should live, what was a good and what was a bad way to live, and real wisdom was surrender oneself to God's will.

For philosophy this meant the end of its claim as the kingly way to wisdom. Facing God's guidance thru His revelation, philosophy as teachings of final wisdom evaporated. Philosophy was human speculation while in religion God Himself spoke. But this did not mean the end of philosophy. In the opposite. Being freed from the weight of producing wisdom philosophy found its real vocation: to expose false truth claims. In other words, monotheistic religions freed philosophy to become critical.

During the Middle Ages philosophy slowly found its new orientation. The great Muslim philosophers like Al Farabi (872-950), Ibn Sina (890-1037) and Ibn Rushd (1126-1178) let themselves be inspired by the great Greek philosophers, by Platon and Aristotle. It were these Muslim philosophers that opened the eyes of European Christian thinkers for Aristoteles. They used philosophy to deeper understand their faith. It is, in a certain sense, a tragic development, that in the Islamic world a coalition of religious jurists (ahli figh) and mystics (suphis) combined to silence philosophy, while in Paris and Koeln monks studied Aristoteles and found that this study deepened their understanding of their religion. At the same time as the writings of Ibn Rushd were burned in Cordova, in Paris developed a philosophical school calling themselves Averoists (Averroes being the Latin name of Ibn Rushd).

\section{ENLIGHTENMENT}

Philosophy found its identity as critical science with the beginning of the period we call Enlightenment, thus with the beginning of the 17th century. Descartes (1596-1650) destructed philosophical beliefs by demanding that philosophy must start not from beliefs, but from universal doubt: nothing may be taken for granted. Thomas Hobbes (1588-1679) and John Locke (1632-1704) tore down the claim of royalty of having been directly empowered by God. Montesquieu (1689-1755) destroyed the claim of absolute state sovereignty by insisting on the rule of law. Voltaire (1694-1778) 
and the Encyclopedists attacked claims of absolute religious power by the Catholic Church. Rousseau (1712-1778) rejected all claims to power that were not based on the sovereignty of the people. They were all essentially critical thinkers.

But primarily modern philosophy directed it central criticism towards false truth claims by knowledge itself. The question, what we can know, where were the limits of accountable knowledge, became the center question of philosophy. It was Immanuel Kant (1724-1804) who made critique the essence of his philosophical endeavors. In his Critique of Pure Reason he tried to prove that all metaphysical talk was just meaningless, while, in his Critique of Practical Reason he exposed the emptiness of moral talk that could not claim universality.

Kant's influence can hardly be exaggerated. Philosophy really became critique. Not only of philosophy itself as had been the case since Platon and Aristoteles. But against social-political ideological structures supporting existing power relations. Against absolute monarchy, against the Church, against century old structures of class relations, against misuse of language, against simplistic criticism itself.

For Kant enlightenment was a moral duty. He had given the famous, and in my opinion still marvelous definition of enlightenment which I want to quote here again in full: "Enlightenment is man's emergence from his self-incurred immaturity. Immaturity is the inability to use one's own understanding without the guidance of another. This immaturity is self-incurred if its cause is not lack of understanding, but lack of resolution and courage to use it without the guidance of another. The motto of enlightenment is therefore: "Sapere aude! Have courage to use your own understanding! Laziness and cowardice are the reasons why such a large proportion of humans gladly remain immature for life" (Weger, 1981, p 111).

Thus, Kant criticizes humans for not having the courage to use their own intellectual power. Thus dogmatism and fundamentalism are not so much a sign of stupidity than of a lack of courage. In Kant's eyes refusal to open up to critical questions, banning free thinking and free discussion, is a sign of moral weakness (and, 
indeed, it is shameful if an university cancels a discussion about controversial matters, like f. i. LGBT, because of outside pressure. Universities should be in the forefront of places where freedom of opinion and discussion is promoted and, if necessary, defended. Let us not fall behind Kant again).

\section{COMES HEGEL'S DIALECTICS}

Hegel (1770-1831), like Kant, hated philosophically dressed opinions, puffed-up as truth. For Hegel, a single position could never be the whole truth. There are no isolated elements. Every opinion has its whence and its where to. Allow me to read in German one of his most famous sentences (from the Introduction to his Phenomenology of Mind): "Das Wahre ist das Ganze. Das Ganze aber ist nur das durch seine Entwicklung sich vollendende Wesen", in my own clumsy translation: "What is true is the whole. But the whole is only reality perfecting itself by its development". Truth is the whole, but truth is an ongoing process where the preceding stages are both negated and affirmed and that, itself, becomes a stage to a more truth. In other words, according to Hegel philosophy is the quest for truth, but truth can only be achieved dialectically.

In Greek philosophy dialectics meant the art of sharp argumentation. Kant used the term with a negative note as clever talking without depth. It is Hegel who recognized the crucial role of dialectics in the quest for truth. The critical power of Hegel's philosophy of dialectics fascinated his students. Karl Marx - while sharply criticizing Hegel's "idealism" - was up to his end proud being an learner on Hegel (when the young Marx talks about "philosophy" he always means just Hegel). Dialectics according to Hegel meant, that truth always, and only, could be achieved as a movement of negativity, as movement of negating each other, of thesis and antithesis. The term "dialectics" means subject against substance, process against smug self-contendedness (kemapanan), progressing rationality against equilibrium, movement towards freedom instead of closing oneself up, negativity against positivity.

Thus according to Hegel a thesis is only true if it is negated by its antithesis. This means among others, that what is specifically Hegel is not the triad thesis, antithesis, synthesis (although Hegel 
himself uses many triads), but an ongoing process where the thesis is negated by its antithesis which immediately becomes itself a thesis that has to be negated again by its new antithesis. And so forth. What is typical for Hegel's antithesis is that they do not just reject the thesis, but at the same time retain its truth. Which is typical for a good dialog. What the first speaker says is negated - corrected, shown its limitation a. s. o. - by the second speaker, but its truth is preserved, and so it goes on and on. This means, truth is precisely not achieved by conforming to a kind of agreement where everybody, for unity's sake, is holding back. In this way progress is impossible and truth will not be achieved. If you want truth, if you want progress, don't be afraid of conflict. Positivity - which for Hegel is of course important - can only be achieved thru a process of negativity, thus in a process of negating each other.

Allow me a note. If we want to get to truth by way of musyawarah and mufakat, we have to get out of pure ethics of harmony. Ethics of harmony resolve conflict essentially by returning to the former harmony. That means that progress is impossible. Ethics of progress mean ethics of clashing opinions thus we must learn to disagree and to have disputes among us. We have to learn what in German is called a Streitkultur, a culture of disputing, without being afraid of disagreements, but without becoming emotional. Sepi ing pamrih, holding back of one's own opinion in order not to make others feeling unpleasant, doesn't help us further. And in educating our children we have to help them to express themselves freely, their ideas, there questions, their doubts, their disagreements, but with an open, easy going emotionality.

But dialectics do not mean that history is going hazardless from one dialectical moment to the other. Hegel believes that he detected direction in the course of history. Behind apparent incidentally and pure chance, the result of conflicting powers, Hegel sees the Spirit at work, God's Spirit, the Weltgeist, who directs from a more fundamental, I would say metaphysical, background what happens in the world of appearances. Thru our individual motivations and decisions, behind the conflict of cultures, communities and states, the Weltgeist is at work. And the Weltgeist edges the world to realizing 
what is the sign of the Spirit, to ever growing rationality and freedom.

Thus, history is not chaotic. It is inexorably moving to greater rationality and freedom. Hegel shows this quiet movement both in his Phenomenology of Mind and in his philosophy of history in the Encyclopedia and other places. There is one crucial element in this movement of the Weltgeist behind the curtain of day to day happenings. Namely that we, the philosophers, understand. Understand that there is real progress behind the superficially of the seemingly chaotic movements on the world stage. Understanding means for Hegel reconciliation. Reconciliation with negativity. There are many seemingly unreasonable, even cruel things happening in world history. But for Hegel, the philosopher understands. He understands that negativity is necessary, that history, and, let us say, humankind, can only progress dialectically, meaning through negativity. That there are victims in history is not in vane, it contributes to the progress of humankind in rationality and freedom. Humankind is necessarily improving, but this is not possible without negativity. Thus, in Hegel's view negativity is reconciled because it, too, is a necessary condition for real progress.

At this place, of course, we should enter into the most vexing question theology: Why is there in this world, created by an almighty and loving God, so much suffering? Thus the question of theodicee. It is the most serious challenge to belief in God that is possible. But I shall not enter into theology here. It was Hegel's conviction, underlying his whole understanding of history, of the Weltgeist, of human development, that we have to understand suffering, injustice, brutality, annihilation as the necessary negativity on the way of humankind to greater rationality, freedom and, we may say, positivity. Of course, Hegel could not get away with this.

\section{CRITICAL PHILOSOPHY}

Only a few years after the death of Hegel, Karl Marx (18181883) entered the stage. As I said, Marx admired Hegel's philosophy. He was proud that, later, at a time when Hegel was treated as a "dead dog", he was saving Hegel's heritage (and we may note here 
that it was the "Hegelian left" that brought Hegel again into the center of philosophical awareness in the 20th century).

But Marx found immediately the weak point of Hegel's philosophy: Hegel thought of a rational world while in the real world irrationality ruled. As he commented Ludwig Feuerbach (1804-1872): "The question is not how to interpret reality, the question is how to change it" (Marx, 1969) In his German Ideology Marx already broke down the rationality of ideological justifications (Marx \& Engels, 1969). Hegel's philosophy was in Marx analysis typically the ideology of the upper classes. The upper classes enjoyed the honey side of reality, and it was easy, and reassuring for them that a Hegel said that suffering and injustice was unavoidable for the greater progress of humankind. That it was even a sign of rationality.

Thus, by uncovering the ideological list of Hegel's philosophy Marx showed that history written by Hegel and in the "understanding" way of Hegel was the history of the winners. Not humankind was progressing to greater rationality against all suffering and injustice, but the winners, the lords, the sultans, the aristocrats, the capital owner. Marx did not dispute that there was a progress to greater rationality and freedom - just read the Communist Manifesto - but he said, this progress will only become universal when the subjected, the lower classes, take their destiny in their own hands. The monopoly on power by the upper classes has to be broken by revolution.

The interesting thing is, as Marx shows, that Hegel's understanding of the truth of history in final analysis was untruth. Untruth that had to be dialectically negated. Reconciliation over the bodies of the victims of history is a false reconciliation. In Indonesian, progress by using humans as tumbal, as the necessary victims for the progress of the community, is false progress. In our today's languages: The concept of human rights is the fruit of our insight that the progress even of 999 people should never be paid for by sacrificing 1 person as victim. It is the merit of Karl Marx that he has uncovered the falseness of reconciliation ideologies that have been formulated by the victors.

It was the critical theory of the 20th century that developed Marx's insight further. Max Horkheimer (1895-1973) in his iconic 
Traditional and Critical Theory showed that history to become true, must be written from the point of view of the victims, and not of the victors (Horkheimer, 1970). In simple language, we have to really know the price in suffering and injustice that went in our actual social-cultural-political reality. Theodor Wiesengrund Adorno (19031969), in his Negative Dialektik, goes a step further (Adorno, 1996). Adorno attacks what he calls Hegel's philosophy of identity. Meaning Hegel's claim that history, including he black secrets and cruelties, should be understood as march of the Weltgeist to greater rationality and freedom. Thus that the fact that there were always victims should be understood as necessary and therefore justified. Adorno points to Auschwitz (the place in Poland where from 1942 to 1945 about three million Jews were killed by the Nazis). Adorno asks whether after Auschwitz philosophy is still possible. Auschwitz is so terrible that any attempt to philosophically find sense in it is itself a crime. We can only say: never again. The terrible point is that before and after Auschwitz there have been many other "Auschwitz". Facing "Auschwitz" philosophy is challenged to reject any half-truths and false truths, thus untruth, and say the truth. But saying the truth for Adorno here means stop saying anything because whatever you say makes you an accomplice. In the face of Auschwitz any attempt at reconciliation is deeply dirty and a crime. Thus philosophy, if it wants to unmask untruth sometimes has to stop talking.

The American philosopher Richard Rorty (1931-2007), coming from a very different, essentially pragmatic position, comes to the same conclusion. Rorty distinguishes between two kinds of liberals, liberal meaning people that want to act in an ethical way (Rorty, 1989). There are liberal ironists and liberal metaphysicians. A metaphysician, for Rorty, is a person basing himself on metaphysical principles, be they ethical or religious. A metaphysical liberal, then, is a person that only acts ethically if he finds a metaphysical reason to do so. Thus, he helps a person in need not because the person is in need, but because, for instance, there is a verse in his Holy Book that tells him to do so. If he does not find a fitting verse, he lets other people die of hunger or thirst. Metaphysical liberals for Rorty are an abomination. These are people without a heart. If they find a metaphysical justification, or a corresponding verse in their holy 
book, they will kill you cold-bloodedly, and when they do cruel, evil things because of a religious justification they might even believe that they get a free entry pass to heaven (I would not like to be in the same heaven with them).

The opposite figure is the liberal ironist. By ironist Rorty means a person that is always aware that his of her convictions are connected to his or her own final vocabulary and that she or he just might get to know another vocabulary which would mean that she has to revise he convictions. Thus, a Rortian ironist does not take herself or himself completely serious. He or she always is aware that another vocabulary could bring her to change or develop her convictions. For a liberal ironist there is only one fundamental principle that under no circumstances can be changed: never act in a cruel way. Thus, f. i., never humiliate, never insult, never make another person suffer (if you can avoid it, of course; a dentist might have to make you suffer a bit). If we ask Rorty on what basis he can say so, his answer is the same as Adorno's: Either you know this, or you are a bastard, an evil person. If you ask, why should I not be cruel you are a dangerous, evil person, better to be avoided. A "normal" ethical person needs no reasons to know that she should not insult, attack, torture or kill another person. If she or he does not know this from their own heart, they are dangerous.

Thus, to summarize our stroll thru the garden of philosophy: Philosophy was critical from its very beginnings. With the entry of religions of revelation (agama-agama wahyu) philosophy concentrated itself more and more on its critical function. But same as its teachings of wisdom, so its critique always was motivated by philosophy's quest for truth, or, better, by its visceral resistance to untruth, especially untruth that came along under the cloak of truth, wisdom or ideology. Philosophy became the safeguard against intellectual seduction and fraud. Philosophy, as we saw with Adorno and Rorty, even stands up against a typical temptation for philosophy, claiming being able to explain, and therefore to reconcile, everything. There are moments, where philosophy demands silence.

Let us now ask what role philosophy could play in the fight against post-truth, - a term reminding us of Habermas' respectable pronouncement that we live in a post-metaphysical time - (whatever 
this may mean). The term post-truth cleverly suggests a kind of respectability of disregarding, or even despising facts. It is the task of philosophy to rip apart any respectability of what is called posttruth. Post-truth is just untruth, point.

\section{WHAT CRITICAL PHILOSOPHY COULD DO IN INDONESIA?}

We here in Indonesia know what post-truth is. Such an amount of half-truths, hoaxes and simple lies as we experienced since the last two years, more precisely since populism was skillfully played to get the governor of Jakarta, Basuki Tjahaja Purnama, better known as Ahok, out of the way and into prison, we have never seen. How low can you go? But of course, you can always still go lower. And they did get lower, they did become still more dirty. After they got Basuki Tjahaja Purnama they went for the jugular of no one less then President Joko Widodo himself, or Jokowi as we know him. He was called a crypto communist, they spread the news that he didn't like Islam. They did not succeed. Jokowi got an impressive majority of the votes of the people. But one still has a bad taste in one's mouth. And probably, most of the 68 million voters that voted against Jokowi did not so, because they were convinced that his competitor would be a better president - of course a democratically completely acceptable opinion, - but because they believed slanderous insinuations and hoaxes about Jokowi.

But let as leave actual politics. I want to point to three complexes of untruth that seemingly have become truth, thus posttruth, one that happened more than half a century ago and still makes it impossible for the Indonesian nation to confront and accept its history. The other two are at this time endangering our Pancasila based democracy, the most impressive breakthrough after the fall of New Order leader President Suharto.

\section{IS PANCASILA INVINCIBLE?}

Only a few days ago the Indonesian state celebrated "the day of the invincibility of (our state ideology) Pancasila": Hari Kesaktian Pancasila. The celebration were praise to the Lord, already quite low key. Nevertheless, it is worth to reflect a little bit upon it. 
One thing is clear. Pancasila is not sakti and cannot be sakti. Pancasila is as strong as people keeping to Pancasila are strong. But "hari kesaktian Pancasila" is not only a misnomer, it is nothing less than a truth that is an untruth. Yes, on October 11965 six generals and a colonel were brutally murdered, extremely brutally, by leftist military, said, probably correctly, with the Indonesian Communist Party PKI behind. And these murders certainly had to be punished. And the attempt of this 30th September Movement to take over power in Indonesia had to be crushed. And it was crushed, within less then 24 hours. But then the lies, and behind the lies, the real crimes only began. On October 3 the corpses of the murdered military were retrieved. They received an official visum et repertum. Which said that all seven corpses were killed by bullets, that there were also bruises at some of these corpses. Nothing else. At that place the now standing Monument Pancasila was built. But from the very beginning it was announced that the still living kidnapped were not immediately killed. That members of Gerwani, the communist Women Organization, danced naked around them, that after they too were shot, these Gerwani women cut off their genitals and cut out their eyes. This dirty lie was later replayed in a film that war shown on national television for more then 20 years every night of October 1. It deeply influenced Indonesians, painting Gerwani as women devils. While in fact Gerwani never did everything wrong. This lie about Gerwani was used to arrest tens of thousands of Indonesian women that were members of Gerwani. Many of them were tortured, raped, forced to stand naked on tables to be checked for communist tattoos (which they did not have), their social existence was destroyed. The about 1.5 Million members of Gerwani were stigmatized as devils, socially killed up to this day. "Kesaktian Pancasila"?

And then began one of the most terrifying genocides of the second half of the $20^{\text {th }}$ century. Beginning October 1965 in Central Jawa and moving through the whole of Indonesia - the latest murders were in June 1966 in East Nusa Tenggara - communists, or suspected communists, were arrested, tortured, and killed. Colonel Sarwo Edhie, who lead the cleansing of "Communists" in Yogyakarta and Central Jawa, boasted that in all three million communists had 
been killed, a number that is generally is regarded as too high. Estimates now vary between 500.000 and two million killed. These people were completely innocent, members of a legal political party, they had nothing to do with the killing on October 1. Besides, according to Admiral Sudomo, almost 2 million people were arrested. More than 200.000 were held in concentration camps from 1965 or 66 till 1978, without ever being brought to trial. Since also the families of those killed or detained were publicly stigmatized, it can be said that the life about 20 million Indonesians were destroyed. Pancasila sakti? Or was it the greatest treason against Pancasila ever committed in Indonesia?

\section{PANCASILA DEMOCRACY}

Allow me to express my conviction that the democratic renewal after the resignation of President Suharto in 1998 was the most important achievement of what we call Reformasi, The Reform. The interesting fact is that $\mathrm{I} t$ were mostly politicians with a clear Islamic identity that made democratizing of Indonesia possible: the successor of Soeharto, Prof. B. J. Habibie, his successor Abdurrachman Wahid, and particularly Prof. Amien Rais who as head of the first People's Consultative Assembly (MPR) pressed for extremely important amendments of the old constitution of 1945, putting into it decisive democratic safeguards and, so very important, almost the whole set of human rights.

But this democratic renewal is under attack. Almost since the beginning. They say that this democracy is "liberal" and liberalism is alien to Indonesia's culture where agreement (mupakat) is reached by common deliberation (musyawarah) and not by voting. Human rights are said to mirror Western individualism, while Indonesian culture does not insist on my individual rights, but on working together (gotong royong). On the basis of this criticism demands are made that we return to the original constitution which, indeed, is neither democratic, nor does it protect human rights. Truth, or concealed untruth? Already in 1961 the late Prof. Koentjaraningrat found that the traditions of gotong royong were no longer alive in Indonesia, except in the case of deaths in the community (Koentjaraningrat, 1961). How cooperatives (koperasi) failed you can read in Selo 
Soemarjan's Social Change in Jogjakarta, written in the fifties! Individualism, understood as orientation to one's individual success and happiness, can, indeed, be no basis for positive living together (Soemardjan, 1962). But what is conveniently overlooked, is that Indonesian society is since long individualized. Meaning: whether you like it or not, you are standing on your own feet and if you fall, nobody saves you.

I give you four facts. (1) Not a single member of the respected audience in this beautiful hall can live with dignity if she or he does not have an individual working place where she or he is individually being paid or produces goods that can be sold. Even at traditional villages on Java people can no longer live from gotong royong in the community. (2) Not one of us can assure his nourishment if she or he does not have money. Without money you do not exist. (3) The same holds for identity cards, insurance, passports: without official individual papers you are regarded as not existing. (4) And last, not least, our whole education system, beginning with Primary School, is focused on individual performance, and if you show social responsibility by helping your fellow pupil to answer the question during an examination you are punished. No, democracy and human rights are not expressions of individualism, but expressions of respect of human dignity. Criticism of democracy and human rights are essentially the signs of old, traditional feudalism, now becoming neo-feudalism, where the former elites, both civil and military, do not want to accept that all Indonesians own Indonesia and therefore have a right to be involved in choosing representatives and expressing freely what they want their chosen leaders to lead them too. This criticism of democracy and human rights by former feudal classes smells. Its truth does not stand up under scrutiny. It is posttruth.

\section{TRUE RELIGION?}

As in many parts of the world, so too in Indonesia: Religion plays a growing role. Positive roles, and negative roles. Religion claims truth. It is extremely important, especially for religious people, not to allow religion to corrupt people by claiming as truth what is untruth. 
Of course, I do not mean the antique question, of whether my religion is truer than yours. One of the great advances of the understanding of religions about themselves is that we do not have to choose between absolutism and relativism. Absolutism meaning: my religion is the only true one, and the others are all wrong. Relativism: no religion is absolutely true, all are true for their respective believers, thus none is really true. We have learned to hold both attitudes together: Believing in the truth of our own religion, and respecting different beliefs without judging them. Because we are deeply convinced that we have to leave judgment over to the only One who really knows, God (as Jesus says: "don't judge if you do not want to be judged yourself", Mr. 7, 1).

No, by truth claims that have to be exposed as untruth I mean something else. I mean ideological exclusivism and religious fanaticism. Ideological exclusivism we can find in religiously based rejection of Pancasila. The big majority of Indonesians are convinced that Pancasila and religion support each other. But there are people saying, we have to reject Pancasila, because we embrace our religion. As if acknowledging the five principles of Pancasila as the fundamental values, ideals and ethical norms of Indonesian politics meant sidelining religion. But Pancasila doesn't stand in competition to religion. In the opposite: Pancasila is the national consensus of the Indonesian people that we all are Indonesians, we all own Indonesia, precisely in each of our religious (and ethnic and cultural) identity. Pancasila is the consensus that Muslims, Catholics, Hindus and all other religious communities can fully live according to their deepest aspirations by being Indonesians. In other words: our Indonesian identity does not suppress, but protect and raise our religious identities so that we can live together in peace, respect and sympathy for each other. Only a religious attitude that is exclusivist, that demands that only my community has the right to govern all of us cannot accept Pancasila.

The same holds for religious fanaticism within one's own religion. Fanatics say: you have to live your religion 100\% - which of course is quite correct, - and this means that, although you think, you belong to my religion, you are in fact still a kafir, because you do not follow what I regard as the right way of my religion. Fanatics, in the 
name of true religion, condemn openness and plural expression within their own religion, and they want to suppress this plurality by force, sometimes by murder. They have their own definition of fullness of truth, kaffah, and whoever differs is a kafir to be eliminated. Why can such an attitude not be truth? Because no human, not a pope or bishop, not a clergyman or -women, no ustadz or kiai, no bikku or pendeta has the mind of God. Only God knows the full truth, and a human, claiming to know with absolute certainty what is the truth about his or her own religion is not only wrong, but such a claim is blasphemy because it means to claim to have the mind of God. Claiming to know the absolute, full truth about one's own religion is untruth, and since in the name of this untruth people are being persecuted, this untruth of religious fanatics has to be exposed. In other words: A religious declaration or confession can only stand up if it is proclaimed with humility. Arrogance and violence are clear proof that the way of God has been abandoned. The sign of truth on the way of God is humility, openness of heart, non-violence, unending goodness of heart.

\section{CONCLUSION}

We are living in a world where untruth under the name of posttruth tries to get some respectability. This respectability itself is a lie, it is untruth. As Hegel shows, we might never be able to come to an end on our search for truth. Certainly philosophy will never proclaim final truths. Philosophy should, humbly, limit itself to critique. Unrelenting critique of half-truth, untruth, prejudices, superficiality, laziness of intellectual inquiry, dogmatism, intolerance and fanaticism under the appearance of religious truth, popular prejudices, identity claims, and other forms of untruth. It is clear, we in Indonesia need philosophy: Critical philosophy, philosophical discourse and debate, openness. Thus, my last appeal, do not let anybody take away our now constitutionally guaranteed freedom of information, freedom of speech, freedom of criticizing, freedom of assembly and freedom of association. Do not allow the state, or religious guards (as you have them already in Aceh), or whoever to intrude into our privacy. By defending these freedoms, we defend the space philosophy needs to give its contribution that we, 
Indonesia, can live together in respect for our plural Indonesian identities, in peace and openness, in intellectual astuteness, in mutual esteem. Philosophy will not surrender to post-truth because its heart is the critical search for truth.

\section{REFERENCES}

Adorno, T. W. (1996). Negative Dialektik. In Gesammelte Schriften. Frankfurt: Fischer Taschenbuch Verlag.

Horkheimer, M. (1970). Traditionelle und kritische Theorie. Frankfurt: Fischer Taschenbuch Verlag.

Koentjaraningrat. (1961). Some Social-Anthropological Observations on Gotong-Royong Practices in Two Villages of Central Java. Ithaca, N. Y.: Cornell University.

Marx, K. (1969). Thesen über Feuerbach. Marx-Engels Werke, Vol 3, 535.

Marx, K., \& Engels, F. (1969). Die deutsche Ideologie (1845). MarxEngels Werke, Vol 3.

Rorty, R. (1989). Contingency, Irony and Solidarity. Cambridge: Cambridge University Press.

Soemardjan, S. (1962). Social Changes in Jogjakarta. Ithaca N. Y.: Cornell University.

Weger, K.-H. (1981). Der Mensch vor dem Anspruch Gottes. Graz etc.: Styria.

Wibowo, A. S. (2019). Posttruth. Basis, (5-6), Vol 2. 